\title{
Germany's attitude towards the association agreement between the European Union and Ukraine ${ }^{1}$
}

\begin{abstract}
The author represents the opinion that before the revolution in Kiev (Euromaidan) at the turn of 2013/2014 Germany had not been interested in Ukraine. Attempts to establish closer contacts with Kiev were blocked by Moscow. The oligarchic system prevailing in the country discouraged the EU from making solemn commitments to Kiev. It was only after the Russian occupation of Crimea that Germany became more active, and with its help the association agreement between the European Union and Ukraine was concluded.
\end{abstract}

Key words: Germany, Ukraine, Association Agreement

In the late $19^{\text {th }}$ century, Ukraine was a part of the Russian Empire and as such was of considerable interest to Berlin. In 1890, following the resignation of Chancellor Otto von Bismarck, who encouraged amicable relations with Russia, Germany adopted a policy of confrontation and war with France and the Romanov Empire. During WWI Germany and Austria-Hungary supported the Ukrainian national movement, inciting Ukrainians to rebel against the tsar. German sympathy with Ukrainian nationalists goes back to that time and survived until the outbreak of WWII. Much to Ukrainians' disappointment, the Third Reich did not meet their expectations, and Ukraine did not gain independence. Following the emergence of the USSR, Ukraine slipped into oblivion in the German collective memory (Torzecki, 1972).

The establishment of an independent Ukraine in 1991 did not raise Germany's interest in that region of the Old Continent. The sluggish, post-Soviet Ukrainian market did not represent much value to Germany. In its eastern policy, Berlin followed the Russia first! rule. Efforts were made not to express any intentions or involvement in Kiev's affairs that Moscow could have interpreted as unfriendly. Unlike the US or Poland, these countries ignored even the geo-political problems related to security (Fałkowski, Lang, 2004; Koszel, 2008a).

Germany was the first Western European country to acknowledge Ukraine's independence, on December 26, 1991, and to establish diplomatic relations in early 1992. However, much to Ukrainian politicians' chagrin, there was no new Marshall Plan, or the expected generous assistance for democratic reforms. Ukraine was not covered by German media, not mentioned in politicians' statements or in economic circles. The expected official bilateral treaty of friendship and partnership in Europe was not signed in Kiev, the way it had been initialed by Germany with nearly all the Central European

${ }^{1}$ This paper has been written as part of a research project of the National Science Centre on the Role of Germany in the European Union's decision-making processes in the $21^{\text {st }}$ century. UMO-2014/15/B/ HS5/00723. 
countries in the early 1990s. Just like the US and the other European countries, Germany wanted to have nuclear weapons removed from Ukraine and to have the Chernobyl Nuclear Power Plant closed down (Kryvonos, 2008).

Ruled by Presidents Leonid Kravchuk and Leonid Kuchma, Ukraine was interested in expanding cooperation primarily with Germany, yet the other party did not respond in the desired way. While the Federal Republic of Germany had signed 15 various detailed agreements (including cooperation in culture, environmental protection, technical consultancy and assistance, youth exchanges or giving up nuclear weapons) with Ukraine, this did not open the door for closer collaboration (Vertragsrechtliche Grundlage, 2008).

More successful were the relations with the European Union, which was striving for stability across Eastern Europe. On June 12, 1994, a Partnership and Cooperation Agreement (PCA) was signed in Luxembourg to construe the rules of future cooperation for at least 10 years ahead (Kost, 2012, pp. 42-43).

In the autumn of 2004, for a short time, public opinion in Germany was delighted with the Orange Revolution and the festival of freedom on the Maidan. Inspired by Poland, Germans unwillingly, yet deliberately played a certain role in resolving the conflict and repeating the presidential elections (Koszel, 2008b, pp. 109-110). However, this resulted chiefly from pressure exerted by German public opinion and the media. It was a tough decision for Chancellor Gerhard Schröder who only that April had entertained Vladimir Putin, President of Russia (the only guest of such high rank), at his birthday party in Hannover. This decision enforced a verification of Ukraine's status in the Russian sphere of influence. When the Chancellor gave a speech in the Bundestag, he had to admit that vote rigging took place during the elections in the Ukraine that could not be ignored. Joschka Fischer, the then Minister of Foreign Affairs, did not exclude the possibility of repeating the elections only after the parliament's summoning to examine the objections.

Once the parliamentary elections were repeated and the "orange" team seized the victory, headed by Victor Yushchenko and Yulia Tymoshenko, before the autumn Bundestag elections in 2005, the member states were strongly divided with respect to Ukraine's access to the European Union. Poland, the Baltic and Scandinavian States promoted quick plans for Kiev and Brussels, and clear accession prospects for Ukraine. In France and the UK, these discussions were treated as premature. The Mediterranean countries were not interested in Ukrainian affairs. Carefully avoiding reference to membership, Germany only promised far-fetched assistance in nurturing the Republic's relations with the EU (Schneider/Sauerbach, 2005).

Since autumn 2005, A. Merkel's coalition of the Christian Democratic Union, the Christian Social Union in Bavaria and the Social Democratic Party of Germany kept its distance from G. Schröder's former strategy: preference for relations with Russia and discrimination of Kiev. Due to the authoritarian conduct of the Russian administration and abuses of freedom of speech in Russia, Germany was more cautious when referring to the "strategic partnership" with Moscow. This automatically improved the country's relations with Ukraine, which was largely impressed with A. Merkel's suggestion that Dietmar Stüdemann, an experienced diplomat and the former German ambassador to Kiev, would assume the position of Victor Yushchenko's European affairs consultant. At the Weimar Triangle summit held in Mettlach on December 5, 2005, the heads of 
the German, French and Polish governments made categorical statements in favor of intensifying cooperation with Ukraine, especially in the realm of immigration and border security. They agreed on granting support to the new comprehensive agreement with Ukraine together with a free trade agreement between the EU and Ukraine (Jendroszczyk, 2006).

The victory of the Orange Revolution and the first attempts at reforms resulted in Germany's greater interest in the country's problems. Since 2006, "Ukraine-Analysen" has been published online twice a month. The magazine has enjoyed good content-related evaluations of the latest developments in Ukraine, research reports, statistics and forecasts. They are published under the auspices of the Forschungsstelle Osteuropa, a research institute associated with the Deutsche Gesellschaft für Osteuropakunde and financed by Otto Wolff-Stiftung (Ukraine-Analysen).

Promising symptoms in the German and EU policies coincided with the parliamentary elections in Ukraine and a split in the "Orange" team. Following the victory of the pro-Russian Party of Regions on March 26, 2006, Viktor Yanukovych increased his power as the Prime Minister. The European Union's negotiations about extending the PCA (an act of key importance to the EU and Kiev) came to a standstill because the agreement was not supposed to include provisions about the possible membership of Ukraine in the EU. Prime Minister V. Yanukovych, who took over the foreign policy initiative from the President, did not even hide his disappointment. However, he admitted that it was a good moment to shift the stress in Ukraine's foreign policy and bring the country closer to Russia (Lindner/Meyer, 2006).

During the German presidency in the European Union in the first half of 2007, which coincided with political destabilization in Ukraine, efforts were made to implement the European Neighbourhood Policy (ENP). As part of the ENP, Berlin did not raise the prospects of Ukraine's membership, but rather promised a strategic partnership, participation as an observer in the working of EU institutions, advice in the realms of security policy, access to EU funds and, first and foremost, inclusion in political decision-making. In this way, Ukraine could gradually adjust to EU standards. As part of the new, "in-depth" system negotiated from March 2007, by 2010 the EU would hand over to Ukraine's disposal the amount of EUR 500 million, together with suggestions for new structural reforms, creating better conditions for foreign investment in the country, Ukraine's contribution to Europe's energy security and reinforcing Kiev in solving regional conflicts, especially in Transnistria. The new treaty, according to which a free trade area was to be established between Ukraine and the EU was planned to be signed on September 14 at the common Kiev summit (Lindner, 2007, p. 5).

In the face of the warning signals from Kiev, and the need to achieve a new agreement, Germany decided to invite Prime Minister V. Yanukovych and find out about his opinions on the country's relations with the EU and Russia. In late February 2007, the Ukrainian Prime Minister made it very clear in Berlin that integration with the EU remained Ukraine's priority. In her negotiations for the new Partnership and Cooperation Agreement, Chancellor A. Merkel emphasized that the new goal of the agreement would be the establishment of a free trade area between the EU and Ukraine, as well as granting support to the country's efforts to enter the World Trade Organization. A. Merkel ensured that Ukraine played "a special role" in EU policy and declared Ger- 
many's support for all the endeavors aimed at reforming Ukraine, but failed to specify any date of the country's possible accession to the EU (Janukowycz, 2007; Merkel studzi zapat, 2007).

Ukraine was admitted to the World Trade Organization in February 2008, which made it possible to extend the country's cooperation with the European Union. On the one hand, it offered Ukraine the opportunity to start talks with Brussels on the free trade zone, as the country's role had been strengthened. This held true also for Russia, who had failed to become member of the WTO. On February 18, President Yushchenko and Peter Mandelson, the European Commissioner for Trade, announced the commencement of a discussion of the so-called in-depth free trade zone between the EU and Ukraine, which brought hopes of hastening the flow of people and capital. However, the EU politicians did not perceive it as a step forward by Kiev to membership of the EU. During her working visit in Ukraine's capital city on July 21, 2008, Chancellor A. Merkel did not offer more than initialing an association agreement. This was still progress, compared with the former declarations of a new treaty of friendship and partnership. At the same time, the Chancellor warned Ukraine against exaggerated expectations (Rinke/Wiede, 2008; Lange, 2008).

At the $12^{\text {th }}$ EU-Ukraine summit held on September 9, 2008, a decision was made to conclude the EU-Ukraine Association Agreement the following year. Undoubtedly, the decision-making process in Brussels was accelerated by the Russian-Georgian war in August, and Moscow's resistance to withdrawing its troops from the invaded territory. This was an eye-opener for EU politicians, who realized that involving post-Soviet countries in reforms under way in the West's sphere of influence may prevent the repetition of similar conflicts in the future. These conflicts could negatively affect the entire European security. However, there was no unanimity at the summit. In the changed circumstances, Poland, the Czech Republic, the Baltic States, the UK and Sweden were for the Union's positive opinion on Ukraine's membership while Germany, France and the Benelux countries put up resistance ("Maximales Ergebnis", 2008).

In December 2009, at the EU-Ukraine summit, the parties decided that the majority of the work on the association agreement had been completed. José Manuel Barroso, President of the European Commission, was optimistic enough to assume that the association negotiations would near completion by the end of 2010. However, following the presidential elections in January 2010, and the victory of V. Yanukovych and the Party of Regions, Prime Minister Y. Tymoshenko was stripped of her power, and soon penal proceedings were instituted against her. She was arrested and sentenced in December 2011 to a period in a penal colony for embezzlement of money from the oil and gas company Naftohaz.

As V. Yanukovych seemed to have been in two minds, trying to appeal to the EU and Russia, the conclusion in Germany was that a country practically accepting its existence in the Russian sphere of influence was not worth bothering with. This was revealed at the $14^{\text {th }}$ Ukraine-EU summit held in November 2010 when Brussels did not conceal its disapproval of the change in Ukrainian foreign policy. While at the subsequent EU-Ukraine summit held in Kiev on December 19, 2011 the negotiations for the association agreement were completed, in his announcement following a meeting with President V. Yanukovych, J. M. Barroso, President of the European Commission stated that the European 
Union intended to "adopt measures in order to sign and ratify the agreement as soon as possible but it will depend on the political circumstances." He highlighted the events in the Ukraine which made the atmosphere between the EU and Ukraine "difficult" (Szczyt UE-Ukraina, 2011). The prospects of Ukraine's membership of the European Union were out of the question, while Germany and France were unanimous in their opinion that the Tymoshenko case showed Ukraine's lack of readiness for closer relations with the EU. Berlin even tried to cancel the summit, but some countries, including Poland, put forward the argument that holding dialogue with Kiev was the best way to push through political reforms (Bielecki, 2011; Böttger, 2014, p. 96).

As late as March 30, 2012, negotiators representing the EU and Ukraine initialed an association agreement of more than a thousand pages, thus finishing the negotiations commenced in 2007. Only a part of the agreement was initialed: the most controversial issues, related to the in-depth, free trade between the EU and Ukraine, were left for further negotiations. The agreement was initialed on July 19, 2012. However, the date of signing and ratifying the document remained unknown. The EU postponed it, as the situation with respect for the law in Ukraine had deteriorated, and the EU insisted Y. Tymoshenko had to be released (Materniak, 2012; Malinowski, 2012).

Undoubtedly, the release of Y. Tymoshenko and of her transfer for treatment to Berlin (a matter of prestige) probably tipped the balance in the Ukrainian government's reorientation. The EU's emphasis on pressing the government in Kiev and imposing conditions it found hard to satisfy obscured the most important goals of an agreement which had been so difficult to reach. Tymoshenko herself appealed that neither she nor her imprisonment be made obstacles to the agreement between Ukraine and the EU. Ukrainians only gained more certainty of Berlin's and Brussels' ill will when Joachim Gauck, the President of Germany, refused to visit Yalta, and when Sigmar Gabriel, the then chairman of the Social Democratic opposition, threatened to boycott UEFA's Euro 2012, organized jointly by Ukraine and Poland. The suspicion in Ukraine was that it was a deliberate strategy, especially on the part of Germany, aimed at providing a pretext for postponing the association agreement sine die as nobody actually wanted it in the EU (Wieliński, 2012).

However, the initialing of the association agreement was some sort of evidence of Ukraine's pro-European attitude. Despite officially declared neutrality, and a demonstrated willingness to cooperate and build up equally good relations with all partners, the Ukrainian elites headed by President V. Yanukovych were aware that Ukraine had to choose a strategic partner: to consistently strive for integration with the EU, or to join the customs union of Belarus, Kazakhstan and Russia. The first option did not give any guarantee of prompt membership; it also suggested a long and tedious process of talks, negotiations, and above all the gradual introduction of high EU standards. The other variant doomed Ukraine to entering Russia's sphere of influence and failing in the inhabitants' European aspirations.

In February 2013, Leonid Kozhara, the Ukrainian Minister of Foreign Affairs, announced that the prospects for entering into the association agreement between Ukraine and the European Union in 2013 were realistic and that the agreement with Kiev could be signed during the Eastern Partnership summit held in Vilnius in November 2013. An opinion poll conducted in December showed that $52 \%$ of Ukrainians supported acces- 
sion to the EU, one third were against it and 14\% remained uncertain (Szef MSZ Ukrainy, 2013).

Russia destroyed any illusions that it would allow the association agreement to be signed. Earlier, Russia had tried to threaten Kiev with cutting off the natural gas supply and discriminating Ukrainian goods on the Russian market. The fate of this agreement was determined in the course of two meetings of the Presidents of Russia and Ukraine held in Sochi (October 27) and Novo-Ogariev near Moscow (November 9). Press coverage suggested that Russia had offered to launch a program of financial assistance of USD 15 billion (purchase of Ukrainian bonds), lower natural gas prices (a drop from USD 400.00 per cubic meter to USD 268.50) and a promise of continued cooperation in the realm of nuclear energy and the key sectors of industry. V. Putin allegedly also declared that Moscow would not exert pressure on Ukraine to enter the Customs Union, and would support the re-election of V. Yanukovych for President in 2015. The relevant agreements were signed on December 17 in Moscow during the Ukrainian President's visit (Putin verspricht, 2013; Y. Zhuchkova, 2016, pp. 38-43).

On November 21, 2013, the Ukrainian government announced that the preparations for initialing the association agreement and that of the in-depth, comprehensive free trade zone with the EU had been halted. Clearly, President V. Putin had outbid the European Union in his promises, as the EU suggested barely EUR 610 million-1 billion, very little for a country in an extremely difficult economic situation with barely USD 20 billion in reserves. At the summit of the Eastern Partnership in Vilnius, Yanukovych allegedly said candidly to Chancellor Merkel that he had expected "much more" from the EU and that he was disappointed (Bidder, 2013).

President Yanukovych's unwillingness to build closer relations with the European Union triggered off mass protests in the Kiev Maidan. The opposition demanded that the President be removed from office. As the days went by, the demonstrators' attitudes became hardened. The brutal dispersal of the protesting crowd on 30 November 30, 2013 by the militia (the "Berkut") caused an upsurge of indignation and popularized the movement. The protests spread all over the country, reaching a peak on December 1, 2013, when the number of demonstrators in Kiev amounted to 800,000. In the western part of the country, the buildings of the central and local administration were occupied by the protesters; similar attempts in the east were moderately successful (Skruwa, StudennaSkruwa, 2015).

In their response to the population's pro-EU aspirations, the Berkut troops did not hesitate to use guns, and blood was shed on the barricades. On February 22, 2014, the Supreme Council of Ukraine passed a resolution stating that Yanukovych no longer held the office of president, which he did not acknowledge. One day later, the Council appointed its chairman, Oleksandr Turchynov head of the country (Stykow, 2014, pp. 41-60).

From the very beginning, a majority of German and even more so French media sympathized with the demonstrators, but politicians called for calm and an amicable resolution. A widespread opinion was that the situation could not be ignored, and that the bloodshed in the streets of Kiev should be stopped. Journalists and ordinary people alike adopted a friendly attitude towards the "revolution of dignity," and the Ukrainian choice of a "democracy and state based on justice and integrity," the choice made on the Maidan barricades. To the French it was reminiscent of the romantic slogans of the 
French Revolution, to Germans, of the Fall of the Berlin Wall and the desire for unity, so the two nations understood perfectly the democratic aspirations of Ukrainians (Berwanger, Karsten, 2014, pp. 41-43).

The fiasco of Ukraine's association agreement with the EU coincided with the forming of a government coalition following the parliamentary elections of September 22, 2013. In an agreement of November 27, the major coalition representatives - Chancellor Merkel on behalf of the Christian Democratic Union/the Christian Social Union in Bavaria and Vice-Chancellor Frank-Walter Steinmeier on behalf of the Social Democratic Party of Germany declared their willingness to intensify and standardize the European Neighbourhood Policy. They decided that the idea of the Eastern Partnership worked, and that the best instruments of support for the eastern neighborhood included association agreements and free trade agreements as well as visa amenities. Unlike Russia or Turkey, Ukraine was not mentioned (Deutschlands Zukunft, 2013).

In Germany, the Ukrainian refusal was met with astonishment. However, officially Chancellor A. Merkel assured that the Federal Republic of Germany and the European Union were ready for talks, and that the door to Europe was still open for Ukraine. The Chancellor referred with distaste to the bidding policy in relations with Ukraine. She indicated the relentless pressure applied by Russia as the major reason for the fiasco of the Eastern Partnership in November in Vilnius; apparently Moscow could not accept losing its sphere of influence. On December 17, in a speech inaugurating his second tenure in the Auswärtiges Amt, Minister Steinmeier could not curb his indignation (empörend) about Russia taking advantage of Ukraine's difficult situation. He also spoke openly about the European Union, which failed to recognize that Ukraine was in dire straits and was forcing the country to choose between Brussels and Moscow, forgetting about Ukraine's historical and emotional relations with Russia (Rede von Außenminister Frank-Walter Steinmeier, 2013).

The efforts to prevent the escalation of the bloody confrontation on Kiev's Maidan and conclude a final agreement between the government and the opposition in February 2014 inspired F.-W. Steinmeier, head of German diplomacy, to look for an amicable solution in Ukraine together with Radosław Sikorski, the Polish Minister of Foreign Affairs and his French counterpart, Laurent Fabius, as part of the Weimar Triangle, reactivated for that occasion (Gonzalez, 2015).

The successful mission of the Weimar Triangle ended with V. Yanukovych's trip to Russia but alleviated the situation only for a short time. Ukraine's attempts at gaining independence from Moscow resulted in masked soldiers, the so-called green men, being sent to the Crimean Peninsula, annexing the area and leading to its official inclusion into Russia on March 18, 2014. The European Union and the USA reacted angrily and did not acknowledge the Crimean referendum as legal. They imposed economic sanctions on the Russian Federation, suspended Russia from the G8 and banned 21 prominent Crimean politicians from entering EU territory (the US banned 31). Jean-Yves Le Drian, the French Minister of National Defense, declared the withholding of military cooperation between France and Russia, which was to relate to exchanging visits, shared military exercise and, first and foremost, the future of two "Mistral" type ships being built for the Russian Federation in the Saint-Nazaire shipyard (Entschlossene Reaktion der EU-Außenminister, 2014). 
Chancellor A. Merkel followed the events in Crimea with concern, but she kept her cool. She responded with considerable restraint to Putin's speech of March 18, and limited herself to stating that it was an act in contravention of international law, but that the sanctions would be accompanied by continued dialogue with Moscow (Sattar, 2014). At the onset of the crisis, she held several telephone conversations with V. Putin about surmounting the Crimean crisis. Before making the decision about imposing sanctions on Russia and the bans on entering Europe imposed on specific Russian citizens, Chancellor Merkel tried to talk V. Putin into resolving the crisis and withdrawing the troops from Ukraine. However, Russia's President adopted an untenable position that there was not a single Russian army soldier in Crimea except for on the Russian military bases. He also indicated the need to protect the rights of Russian citizens persecuted in Crimea by terrorists and Bandera's nationalists.

F.-W. Steinmeier made intensive diplomatic efforts to alleviate the situation. He travelled to the Baltic States and to Budapest, he met Sergey Lavrov, the Russian Minister of Foreign Affairs, hence shifting Germany to the head of the countries involved in resolving the conflict in Ukraine (Wehner, 2014). It was anything but easy, because Germany was very much involved in finding a way out of the euro zone crisis (establishment of a Banking Union) and the paralysis of EU institutions in the face of the imminent elections for the European Parliament (Księżniakiewicz, 2015a, p. 3).

Following a parliamentary discussion in the Bundestag on March 19, 2014, the parties were unanimous in their conviction that military intervention was out of the question. At the same time, it remained uncertain how far Putin would go and what concessions the EU should make. The intent was to play all the instruments, i.e. continue the dialogue with Moscow, extend the sanctions imposed on Russia if need be and continue the financial assistance for Ukraine. The major benchmark was the effort to prevent the crisis from spreading to east Ukraine; to this end, on March 23 Germany put forward a proposal to send OSCE observers to Ukraine (Rinke, 2014, pp. 33-45).

On March 21, 2014, at the time of the Crimean crisis, Arseniy Yatsenyuk, Ukraine's Prime Minister, signed the political part of the association agreement with the European Union in Brussels. This was the immediate response of EU countries to the annexation of the peninsula. At a meeting of the European Council, the act of annexing Crimea and Sevastopol to the Russian Federation was condemned and it was made clear that the EU would not accept the move. As Moscow was not willing to alleviate the situation whatsoever, the Council decided to extend the ban on issuing visas and to freeze the assets; the Council also cancelled the subsequent EU-Russia summit. While the EU was to stay open to dialogue, it did not exclude additional, far-reaching consequences for relations with Russia in "a case of the Russian Federation taking any further measures to destabilize the situation in Ukraine." The Council also decided to accelerate the act of initialing the association agreements with Georgia and Moldova (Rada Europejska 20-21 marca 2014).

The association agreement signed in Brussels was a lengthy document; the preamble included a stipulation that, bearing in mind the strong social support in Ukraine for integration, "the organization acknowledges the European aspirations of Ukraine and is pleased to accept the country's choice including the commitment to build up a robust and lasting democracy and market economy." In the goals section, the most important 
one was identified as "propagating a gradual rapprochement between the Parties based on common values as well as close and privileged relations and the increasing association of Ukraine with the UE policy and a growing participation in EU's programmes and agencies." A promise was made to establish a framework for political dialogue and creating conditions for intensified economic and trade relations as part of Ukraine's efforts to gradually integrate with the EU internal market, including the establishment of an indepth and comprehensive free trade zone (THE ASSOCIATION AGREEMENT, 2014).

Since April 2014, in eastern Ukraine, pro-Russian separatists who had been granted Russia's military support put up armed resistance to the government in Kiev, and announced the establishment of a self-appointed Donetsk People's Republic and the Luhansk People's Republic. Following the annexation of the key cities of the Donbass in May 2014, they proclaimed the confederation of the two republics. As a result, the armed forces of Ukraine embarked on a so-called counter-terrorism mission with the goal of retaking the major cities and the dissolution of the military separatist troops. The conflict escalated when on July 17, 2014 a Malaysian airliner was shot down with 295 people on board. While both parties of the conflict made accusations against each other for the shooting, the EU and the USA responded by applying more sanctions on Russia. An embargo was imposed on weapons; the large Russian banks (at least half of them are state-owned) had less room to maneuver; access to capital markets was obstructed; sales of advanced technologies were banned, as they are indispensable in crude oil extraction from difficult to access deposits and shale oil; and a ban was imposed on exports of double use objects (civil and military) for the Russian defense industry (EU extends sanctions on Russia; Forsberg, 2016, pp. 21-42).

During the escalation of the conflict in eastern Ukraine, in May 2014 presidential elections were held and won by Petro Poroshenko, who enjoyed a good image in the West. On June 27, 2014, Poroshenko signed the second part of the association agreement with the European Union re. the Deep and Comprehensive Free Trade Areas (DCFTA) effective as of January 1, $2016 \mathrm{r}$ (Gipfel in Brüssel, 2014). The agreements were also initialed by the leaders of two other countries, Irakli Garibashvili from Georgia and Iurie Leancă, Prime Minister of Moldova. These agreements necessitated ratification by the European Parliament and the parliaments of EU member states.

After the democratic presidential elections held in Ukraine, Germans strengthened their contacts with Ukraine. On June 7, Joachim Gauck, the President of Germany took part in the inauguration of Poroshenko's presidency. Steinmeier held regular consultations with his Ukrainian counterpart, Pavlo Klimyk. Chancellor Merkel had numerous telephone conversations with the President. On August 23, she visited Ukraine where she declared that the country's territorial integrity and welfare "were the major goal of the German policy." The Chancellor added that Ukraine would be granted a credit guarantee exceeding EUR 500 million for power and water supplies and EUR 25 million as part of assistance for refugees (Merkel will Ukraine, 2014; Merkel w Kijowie, 2014).

Following the NATO summit in Newport and initialing the so-called first Minsk agreement aimed at finishing the fights in eastern Ukraine, on September 16, the Association Agreement between Ukraine and the European Union was ratified concurrently in Kiev and Strasbourg. The Supreme Council of Ukraine adopted it unanimously and on the very same day, the agreement was initialed by President P. Poroshenko. The Eu- 
ropean Parliament also ratified the association agreement by a majority vote (535) with 127 votes against and 35 abstained votes (Ukraine besiegelt, 2014).

Before Germany ratified the agreement, avid fans of Russia and opponents of Ukraine's closer relations with the European Union became very active. The strongly pro-Russian lobby in Germany was typically associated with business circles (especially with Ost-Ausschuss der Deutschen Wirtschaft and its head Eckhard Cordes), pacifist or leftist organizations and those related to culture and entertainment (e.g. the popular Kabarett artist Volker Pispers). They were casually referred to as "those understanding Russia" (Rußlandversteher). Christian Hacke, one of the most famous and renowned German historians and political scientists of the older generation, referred to "reason" when he wrote that "the West has demonstrated considerable naivety in its thinking that the Russian President would look idly at the support granted to Kiev and aimed at associating Ukraine with the western structures [...]. The European stability zone and its extension with Ukraine is geopolitical competition to Russia and its plans of a Eurasian union. Following the defeat of Yanukovych, Putin decided to annex the Crimean Peninsula in fear of a further extension of the western sphere of influence" (Hacke, 2014, pp. 40-47). Different arguments were also put forward, such as that Russia and Germany were a "spiritual community," while the government in Kiev did not consist of democrats but rather corrupt oligarchs. It was necessary to have an understanding of Russia's vital interests in Ukraine, and as Russia's biggest partner, Germany is being pressurized by the European Union to handle issues of no interest to the country. The United States was here to blame with its arrogant attitude, intensifying tensions in Eastern Europe for no reason at all. Ukraine should stop dreaming about membership of the European Union and NATO and remain neutral. The country should not burden Russia with its problems, as the West needs Russia as a partner in countering terrorist activities, in the conflict in Syria and in solving global problems (Teltschik, 2014, pp. 24-29; Priess, 2014, pp. 18-23; Vogel, 2014, pp. 51-65). Other comments, especially those made by the Left Party, indicated that speaking of the "annexation" of Crimea was out of the question. It was a secession, acceptable in the light of international law, resulting from the local population's desire for self-determination as expressed in a referendum. Only after a victory in the referendum was the Crimean Peninsula incorporated into the Russian Federation (Merkel, 2014).

Chancellor Merkel might have been disappointed with the attitude of her coalition partner, the Social Democratic Party of Germany (SPD) as a large part of its members openly demonstrated their aversion to Ukraine and support for Putin. While, in the past, many German social democrats, including August Bebel, the co-founder of the SPD, had regarded Russia as a source of barbarity and an enemy of human culture, the post-war social democrats from Willy Brandt's generation (Generation $W$ ) thought that cooperation with the Soviet Union was necessary and possible, accompanied by entering into a détente dialogue with Moscow. Following Russia's annexation of Crimea the architects of the German eastern policy from the 1970s were among the chief defenders of Russia, including the former Chancellor Helmut Schmidt and his advisor, the late political scientist Egon Bahr. Their opinions were shared by the former Chancellor Gerhard Schröder, Günter Verheugen (the former European Commissioner for Enlargement) and Matthias Platzeck, the former Minister President of Brandenburg (Księżniakiewicz, 2015b). 
On December 5, 2014, "Die Zeit" published its manifesto "Another war in Europe. Not in our name!" In the manifesto, the need to continue the détente policy in international relations was indicated, together with continued dialogue with Moscow, because the need for security in Russia was as justified as it was in Germany, Poland, the Baltic States or Ukraine. Excluding Russia from Europe would be "unreasonable and a threat to peace." The manifesto was signed by the German political, academic and artistic elites including the former Chancellor G. Schröder, President Roman Herzog, the famous film director Wim Wenders and the popular actors Hanna Schygulla, Mario Adorf and Karl Maria Brandauer ("Wieder Krieg in Europa?", 2014).

The German government, supported in the Bundestag by the Green Party and the extra-parliamentary liberals, resisted the blatant propaganda spread in numerous TV programs by "those understanding Russia" and on March 26, 2015, a vote was carried with respect to the ratification of the association agreements with Ukraine, Moldova and Georgia. When justifying the government's motion, Minister F.-W. Steinmeier emphasized that the pact had contributed to the stabilization and peace broken by the fighting in eastern Ukraine. The EU did not create the conflict with Russia, which had annexed Crimea against the law and destabilized the situation in the Donbass. The government enjoyed a majority, as it received the Green Party's support. In opposition was the Leftist Party, according to which Brussels (insisting on Ukraine's closer relations with the EU against Russia's will) should be held responsible for the conflict between Russia and Ukraine. The party also demanded that the sanctions imposed on Russia be lifted. The Bundesrat, the upper chamber of the parliament, ratified the agreement on May 8, 2015 (Abkommen mit Ukraine, Georgien, Moldau gebilligt, 2015).

On January 1, 2016 the agreement between Ukraine and the European Union on the Deep and Comprehensive Free Trade Areas (DCFTA) became effective as the most significant and the largest part of the association agreement signed between Ukraine and the EU in June 2014. The agreement stipulates that a free trade zone will be established and that Ukraine will adopt approximately $60 \%$ of European Union laws, including the regulation of power-related issues, technical, sanitary, phytosanitary, customs regulations and those related to the protection of intellectual property. What is more, the agreement is meant to safeguard a flow of capital and to create equal competitive conditions. On that very day, by virtue of President V. Putin's decision, the agreement on free trade between Russia and Ukraine became ineffective (Anwendung der Handelsbestimmungen, 2016).

As has already been mentioned, the association agreement was subject to ratification by member states. Since the beginning, warning signals were sent from the Netherlands, where the populist Dutch Party for Freedom led by Geert Wilders encouraged protests against closer relations between Ukraine and the European Union. In general, the Dutch expressed their dissatisfaction with the deficit of democracy in the process of making decisions in the European Union. The issue of the relations between the Netherlands, the EU and Russia was a very important element of the debate preceding the referendum, together with the concern that an agreement with Ukraine would lead to hampering contacts with Moscow. The solemn assurances that within the next 20-25 years Ukraine would not be able to join the EU, delivered by Jean-Claude Juncker, President of the European Commission, were perceived as tactical and empty (Juncker schließt Beitritt, 2016). 
As expected, on April 6, 61\% of Dutch citizens voted against Ukraine's association with the EU and only $38.2 \%$ of them voted in favor (voter turnout at $32.2 \%$ ). In the light of the law, no referendum was binding, which put the government in an awkward position, and an attempt was made to find a satisfying legal solution. Germans were very careful in expressing their criticism, highlighting Ukraine's disappointment with the Dutch attitude and Russia's content with the developments. Emphasis was placed on the fact that it was an additional stimulus for populists and opponents of the EU in the other European countries (Reaktionen, 2016; Brech, 2016). On April 21, during German and Dutch intergovernmental consultations in Eindhoven, Chancellor Merkel only stated briefly that the Dutch government and parliament would find an amicable solution and that Germany would not give any relevant advice because it was an internal affair of the Dutch state (Pressekonferenz, 2016).

Proceeding with general reflections, one can state that the EU countries have accepted the dominant role of Germany, but also of Poland in associating Ukraine with European structures. But it is Germany that has made the biggest contribution to resolving the conflict in eastern Ukraine. This is because no other country, other than France, showed a willingness to be more active in this area. It is worth emphasizing that as part of the assistance, in 2014 Berlin handed over EUR 130 million to Arseniy Yatsenyuk's government, approximately EUR 200 million in 2015 and a credit guarantee for EUR 500 million. EUR 8 million was transferred to Ukraine as part of German humanitarian aid (Deutsche Unterstützung, 2016).

By deciding to support Ukraine's European aspirations, Chancellor A. Merkel was aware that Russia had all the instruments at hand to destabilize Ukraine, while many EU countries were simply indifferent to the fate of Ukraine. Except for economic sanctions, Germany and the European Union do not have at their disposal any means of pressure. The suggestions of delivering arms to Ukraine and increasing the EU's military potential have, in Germany, encountered unanimous and increasingly stiff resistance of various types of pacifists and "those understanding Russia." In return for diminishing the pressure on Ukraine, a suggestion has been made to tempt Putin with prospects of further association with the EU and establishing a common economic space (Brami, 2015; Ischinger, 2015, pp. 30-35).

By a majority of opinions expressed by German experts in particular, Ukraine should accept the loss of its two separatist provinces, as the alternative is wider chaos and disintegration of the country. A view has been supported in Germany that Russia had adopted a strategy of the long-term weakening of Ukraine, hoping for internal divisions in the country. Stefan Meister, a famous analyst and expert in Russian affairs from the Berlinbased DGAP Research Institute wrote: "It is an illusion that any compromise can be reached with the Russian government. The conflict with the European Union and the West strengthens Putin's regime" (Meister, 2015). At the same time, suggestions are made for the European Union to specifically declare its intentions towards the "new" Ukraine and to include in a treaty the country's European prospects (Meister, 2015; Rinke, 2015, pp. 36-43). Following the resignation of A. Yatsenyuk's government in April 2016, Chancellor A. Merkel no longer cherishes any illusions about Ukraine. Minister F.-W. Steinmeier and Jean-Marc Ayrault, the French Minister of Foreign Affairs, took a trip to Kiev in February 2016 and shared the impression that the country was still 
plagued by corruption, with an oligarchic economy, deep cultural divides as well as nationalist sympathies (Steinmeier droht, 2016). The reforms are being implemented on the pretext of the war, yet implemented indolently and superficially, while the society is not ready for more sacrifice. However, in the past neither country could accept infringement of the territorial integrity of any European country as it would open up a Pandora's box, especially in the regions of the so-called frozen conflicts.

\section{Bibliography}

Anwendung der Handelsbestimmungen des Assoziierungsabkommens zwischen der EU und der Ukraine beginnt am 1. Januar 2016, Europäische Kommission - Pressemitteilung, http://europa.eu/rapid/press-release_IP-15-6398_de.htm.

Becker M. (2016), Niederländer sagen Nein zu EU-Abkommen: Und jetzt, Herr Rutte?, "Der Spiegel” of April 7.

Berwanger H., Karsten R. (2014), Das demokratische Versprechen. Deutsche Außenpolitik im UkraineKonflikt, "Die neue Gesellschaft/Frankfurter Hefte", no. 61.

Bielecki T. (2011), Szczyt UE-Ukraina: twarda odmowa z powodu Tymoszenko, "Gazeta Wyborcza" of December 19.

Bidder B. (2013), Staatschef der Ukraine: Janukowitschs riskanter Milliardenpoker mit EU und Putin, "Der Spiegel" of November 29.

Böttger K. (2014), Auf dem sicherheitspolitischen Auge blind. Die EU und Außenpolitik angesichts der Ukraine. Zustand und Entwicklungsperspektiven, "Integration", no. 2.

Brami J. (2015), In der Sanktionsspirale. Auch im Interesse der Ukraine sollten wir Russland wirtschaftlich nicht isolieren, "DGAPstandpunkt", no. 1, https://dgap.org/de/article/getFullPDF/26413.

Brech S. M. (2016), ,Nee” der Niederländer bringt EU in große Schwierigkeiten, “Die Welt” of April 7.

Deutschlands Zukunft gestalten.Koalitionsvertrag zwischen CDU,CSU und SPD, (2013), https://www. cdu.de/sites/default/files/media/dokumente/koalitionsvertrag.pdf.

Deutsche Unterstützung für die Ukraine (2016), Deutsche Botschaft Kiew, http://www.kiew.diplo.de/ Vertretung/kiew/de/10/Deutsche_Unterstuetzung_fuer_die_UKR/_Deutsche_Unterstuetzung_fuer_die_UKR.htl.

Entschlossene Reaktion der EU-Außenminister (2014), Die Bundesregierung, https://www.bundesregierung.de/Content/DE/Artikel/2014/03/2014-03-17-krim-eu.html.

Fałkowski M., Lang K.-O. (2004), Wspólne zadanie. Polska, Niemcy, Ukraina w przeobrażajacej się Europie/ Eine gemeinsame Aufgabe. Deutschland, Polen und Ukraine im sich wandelnden Europa, Instytut Spraw Publicznych, Warszawa.

Forsberg T. (2016), From Ostpolitik to ,frostpolitik”?, Merkel, Putin and German foreign policy towards Russia, "International Affairs", no. 1.

Gipfel in Brüssel: Ukrainischer Präsident Poroschenko unterzeichnet EU-Assoziierungsabkommen (2014), "Der Spiegel” of June 27.

Gonzalez M. (2015), Mission commune á Kiev, "Dokumente. Zeitschrift für den deutsch-französischen Dialog", no. 3.

Hacke C. (2014), Der Westen und die Ukraine-Krise: Plädoyer für Realismus, “Aus Politik und Zeitgeschichte" 47/48.

Ischinger W. (2015), Eine Aufgabe für Generationen, der Westen muss gegenüber Russland auf eine neue Doppelstrategie setzen, "Internationale Politik", no. 1.

Janukowycz: Integracja z UE pozostaje priorytetem Ukrainy (2007), "Gazeta Wyborcza” of February 28. 
Jendroszczyk P. (2004), Do Kijowa przez Moskwę. Czy ostatnie wydarzenia zmienia politykę Niemiec?, "Rzeczpospolita" of November 27.

Jendroszczyk P. (2006), Radosny i konkretny Trójkąt Weimarski, "Rzeczpospolita” of December 6.

Juncker schließt Beitritt der Ukraine für Jahrzehnte aus (2016), "Frankfurter Allgemeine Zeitung" of March 3.

Koszel B. (2008a), Polska i Niemcy a europejskie aspiracje Ukrainy, "Przegląd Zachodni”, no. 1.

Koszel B. (2008b), Polska i Niemcy w Unii Europejskiej. Pola konfliktów i płaszczyzny wspótpracy, Wydawnictwo Instytutu Zachodniego, Poznań.

Księżniakiewicz M. (2015a) Niechciany partner. Rola Niemiec w rozwiazywaniu konfliktu na Ukrainie, "Biuletyn Niemiecki", no. 57, http://fwpn.org.pl/assets/Publikacje/Biuletyn_Niemiecki/2015/ BIULETYN_NIEMIECKI_NR_57.pdf.

Księżniakiewicz M. (2015b), Opinia publiczna i elity polityczne $w$ Niemczech wobec konfliktu na Ukrainie (listopad 2013-marzec 2015), "Przegląd Zachodni”, no. 4.

Kost P. (2012), Ukraina wobec Unii Europejskiej 1991-2010, Wydawnictwo Adam Marszałek, Toruń.

Kryvonos R. (2008), Deutsch-ukrainische Beziehungen vor dem Machtwechsel in Deutschland 1998, http://www.oei.fu-berlin.de/media/publikationen/boi/boi_14/28_kryvonos.pdf.

Lange N. (2008), Deutschland-Ukraine: Schwierige, aber wichtige Partnerschaft, "KAS Länderbericht", August 22, http:/www.kas.de/wf/doc/kas_14216-1522-1-30.pdf?080723111229.

Lindner R., Meyer T. (2006), Nach der Wahl: Koalitionspoker in der Ukraine, "SWAP-Aktuell", no. 23.

Lindner R. (2007), Krise der Aussenpolitik und Vermittlungsbedarf für die EU, "Ukraine-Analysen", no. 22, http://www.laender-analysen.de/ukraine/pdf/Ukraine Analysen22.pdf.

Malinowski P. (2012), Parafowano umowę stowarzyszeniowa Unia Europejska - Ukraina, "Rzeczpospolita" of March 30.

"Maximales Ergebnis" - EU bietet Ukraine Assoziierung ohne Beitrittsperspektive (2008), Deutsche Welle, http://www.dw.com/de/maximales-ergebnis-eu-bietet-ukraine-assoziierung-ohne-beitritts perspektive/a-3632804.

Materniak D. (2012), Umowa stowarzyszeniowa czyli kolejny mały krok Ukrainy do na drodze do UE, http://www.psz.pl/index.php?option=content\&task=view\&id=41472.

Meister S. (2015), Politik der Illusionen. Ein Ausgleich mit Russland auf Grundlage einer EU-EWUPartnerschaft ist irrig, https://zeitschrift-ip.dgap.org/de/article/getFullPDF/26490.

Meister S. (2015), Eskalation erwünscht.Warum Minsk 2 nicht funktionieren wird, "DGAPstandpunkt", no. 2, https://dgap.org/de/article/getFullPDF/26457.

Merkel will Ukraine mit halber Milliarde Euro helfen (2014), "Die Welt" of August 23.

Merkel studzi zapat Ukrainy (2007), "Rzeczpospolita" of March 1.

Merkel w Kijowie. Będzie pomoc Niemiec dla Ukrainy (2014), Deutsche Welle, http://www.dw.de/ merkel-w-kijowie-b\%C4\%99dzie-pomoc-niemiec-dla-ukrainy/a-17873498.

Merkel R. (2014), Kühle Ironie der Geschichte, "Frankfurter Allgemeine Zeitung" of April 7.

Pressekonferenz von Bundeskanzlerin Angela Merkel und Premierminister Mark Rutte. Die Bundesregierung, https://translate.google.pl/translate?hl=pl\&sl=de\&u=https: //www.bundesregierung. de/Content/DE/Mitschrift/Pressekonferenzen/2016/04/2016-04-21-bkin-rutte-niederlande. html\&prev=search.

Priess F. (2014), Russland verstehen. Die Deutschen und ihre Krisenwahrnehmung, "Die Politische Meinung", no. 67.

Putin verspricht Ukraine Milliardenkredite und billigeres Gas (2013), "Die Zeit" of December 17.

Rada Europejska 20-21 marca 2014. Konkluzje, http://www.consilium.europa.Eu /uedocs/cms_data/ docs/pressdata/pl/ec/141756.pdf. 
Reaktionen auf Votum der Niederlande: "Das war Anti-Alles" (2016), "Der Spiegel” of April 7.

Rede von Außenminister Frank-Walter Steinmeier bei der Amtsübergabe im Auswärtigen Amt am 17. Dezember 2013, Auswärtiges Amt, http://www.auswaertiges-amt.de/DE/Infoservice/Presse/ Reden/2013/131217-BM_Antrittsrede.html.

Rinke A., Wiede T. (2014), Merkel dämpft Erwartungen der Ukraine, "Handelsblatt" of July 21.

Rinke A. (2014), Wie Putin Berlin verlor. Moskaus Anexion der Krim hat die deutsche Russland-Politik verändert, "Internationale Politik", no. 5/6.

Rinke A. (2015), Vom Partner zum Gegner zum Partner?, Die alte Russland-Politik ist tot - jetzt sucht Berlin nach einem neuen Ansatz, "Internationale Politik", no. 2.

Sattar M. (2014), Wohl oder übel. Deutsche Reaktion auf Krim-Annexion, "Frankfurter Allgemeine Zeitung" of March 18.

Schneider E., Sauerbach C. (2005), Kiew EU-Ambitionen, "SWP- Aktuell”, no. 14, http://www.swpberlin.org/fileadmin/contents/products/aktuell/aktuel12005_14_sdr_saurenbach_ks.pdf.

Skruwa G., Studenna-Skruwa M. (eds.), Rewolucja w imię godności. Ukraiński Euromajdan 2013-2014, Wydawnictwo Adam Marszałek, Torun 2015.

Steinmeier droht Ukraine mit IWF-Zahlungs-Stopp (2016), "Frankfurter Allgemeine Zeitung" of February 22.

Stykow P. (2014), Innenpolitische Gründe der Ukraine-Krise: gleichzeitige Demokratisierung und Staatsbildung als Überforderung, "Osteuropa", no. 5-6.

Szczyt UE-Ukraina. Prezydencja Polski w Radzie UE (2011), http://pl2011.eu/content/szczyt-ue-ukraina.

Szef MSZ Ukrainy: Podpisanie umowy stowarzyszeniowej z UE możliwe w tym roku (2013), EurActiv.pl, http://www.euractiv.pl/rozszerzenie/wywiad/szef-msz-ukrainy-podpisanie-umowy-stowarzyszeniowej-z-uemoliwe-w-tym-roku-004425.

Teltschik H. (2014), Türen nie zuschlagen! Warum der Westen weiter mit Russland reden muss, "Die Politische Meinung", no. 58.

Torzecki R. (1972), Kwestia ukraińska w polityce III Rzeszy (1933-1945), Wydawnictwo Książka i Wiedza, Warszawa.

Vertragsrechtliche Grundlage der deutsch-ukrainischen Beziehungen (2008), Botschaft der Ukraine in der Bundesrepublik Deutschland, http://germany.mfa.gov.ua/de/ukraine-de/legal-acts.

Vogel T. (2014), Überforderung und Desinteresse. Die EU, die Nachbarschaft und die Ukraine, "Osteuropa", no. 9-10.

UE rozszerza sankcje wobec Rosji (2014), "Gazeta Wyborcza” of July 17.

Ukraine besiegelt Partnerschaft mit der EU (2014), "Die Zeit" of September 16.

Układ o stowarzyszeniu między Unią Europejską i jej państwami członkowskimi, z jednej strony, a Ukrainą, z drugiej (2014), http://eur-lex.europa.eu/legal-content/PL/TXT/PDF/?uri=CELEX :22014A0529(01)\&from=PL.

Ukraine-Analysen (2006-2016), http://www.laender-analysen.de/ukraine/pdf/UkraineAnalysen01. pdf.

Wehner M. (2014) Steinmeiers große Illusion, "Frankfurter Allgemeine Zeitung” of March 15.

Wieder Krieg in Europa? Nicht in unserem Namen!, (2014), "Die Zeit” of December 5.

Wieliński B. T. (2012), Tuż przed rozpoczęciem Euro 2012 niemieccy politycy zrobili z Ukraińców chłopców do bicia. A potem jak zwykle o nich zapomnieli, "Biuletyn Niemiecki”, no. 30, http:// fwpn.org.p1/assets/biuletyny/BN30.pdf.

Zhuchkova Y. (2016), Auf dem Weg zu Neu-Moskowien, die Westorientierung der Ukraine ist für Russland eine geopolitische Tragödie, "Internationale Politik", no. 3. 


\section{Niemcy wobec umowy stowarzyszeniowej Unia Europejska-Ukraina}

\section{Streszczenie}

Autor reprezentuje opinię, że do czasu rewolucji w Kijowie (Euromajdan) na przełomie 2013/2014 r. Niemcy nie interesowali się Ukrainą. Próby zacieśnienia kontaktów z Kijowem blokowane były przez Moskwę. System oligarchiczny panujący w tym kraju zniechęcał również UE do podejmowania wobec Kijowa daleko idących zobowiązań. Dopiero po zajęciu Krymu przez Rosję Niemcy się uaktywnili i dzięki ich pomocy doszło do zawarcia przez Unię Europejską umowy stowarzyszeniowej z Ukrainą.

Słowa kluczowe: Niemcy-Ukraina, umowa stowarzyszeniowa, Unia Europejska 